\title{
Safety behavior of in-line skaters
}

\author{
J Scott Osberg, Sarah C Stiles
}

\begin{abstract}
Objectives and setting-Injuries from inline skating have risen sharply in many cities around the world. To understand risk taking behavior and safety practices associated with urban in-line skating, 2210 outdoor skaters were observed in Boston, Massachusetts.

Methods-Estimated age, gender, use of helmets, wrist guards, elbow and kneepads were recorded. Skaters were coded as beginner, average, or advanced, and skating locations were classified as street, sidewalk, or bicycle path.

Results-About $60 \%$ of skaters wore wrist guards, but only $5.7 \%$ wore helmets. Males wore less protective equipment than females, and were more likely to skate on streets. Beginners and advanced skaters wore more protective gear than average skaters. Surprisingly, street skaters wore less protective gear than skaters on sidewalks or paths.

Conclusions-Renewed focus on the importance of wearing helmets is needed. Given the higher injury risks for males, clinicians and public health experts need to target male skaters in prevention efforts. In addition, average and advanced skaters need to be convinced that even though they have improved, it is still important to wear protective gear.

(Injury Prevention 2000;6:229-231)
\end{abstract}

Keywords: protective gear; helmets; skating safety; in-line skating

As recreational in-line skating grows in popularity, and skating becomes a more common mode of urban transportation, ${ }^{12}$ injuries and deaths are expected to rise. ${ }^{23}$ The majority of skating injuries are due to forward falls on outstretched arms ${ }^{4}$ without vehicle, bicycle, or other skater involvement. Most skating related injuries are preventable if time is taken to learn the basics while skating on flat, smooth, dry, surfaces. ${ }^{145}$ In addition, when falls do occur, regardless of skill level, injuries can be prevented or minimized by wearing appropriate protective gear. ${ }^{3}$ Although there are several reports about in-line skating injuries, and on recommendations for protective gear, we found only three observational studies describing use of protective equipment. ${ }^{678}$ Consequently, we conducted an observational study to understand safety behavior of in-line skaters in Boston.

\section{Methods}

The first author observed outdoor skaters from July through September 1996 and April to
August 1997 at 33 locations in Boston's affluent Back Bay neighborhood. This neighborhood has many professionals, few children, and many college students, especially during the academic year. ${ }^{9}$

Four dichotomous variables record use of helmets, wrist guards, elbow and kneepads. The age of skaters is estimated as youngest to age $12,13-17,18-50$, and 51 and over. Although finer age gradations are typically examined, the goal here is to distinguish between children, teens, adults, and older adults by observation. The wide age categories meet the goal and minimize misclassification errors. Skaters were coded as beginner, average, or advanced. Beginners are easily recognized by their comparative lack of control and poor technique. They lack balance (especially when trying to stand still), flail their arms, fall down occasionally, clutch railings, go slower, tend not to stride correctly, and become nervous when confronting bumps, inclines, or other skaters. Advanced skaters appear to be in full control, sometimes skating backwards, doing stunts, or speed skating. They are able to stop quickly and gracefully. The majority of skaters who could not be classified as beginner or advanced skaters were coded as average.

Skating locations were classified as street, sidewalk, or bicycle path, as has been done in other studies of skate safety. ${ }^{6}$ Although this was mainly a study of in-line skaters, because injuries of roller skaters are so similar, ${ }^{34}$ the three observed roller skaters were included. Our exclusion criteria specify that the same skater not be coded twice in the same data collection block, or in contiguous data collection blocks at the same location. However, the same skater could be recorded again later on the same day.

\section{Results}

Table 1 shows demographic and background data on the sample. Table 2 shows the percentage of skaters wearing helmets $(5.7 \%)$, elbow $(10.0 \%)$ and kneepads (22.8\%), and wrist guards $(60.5 \%)$. Females were significantly more likely to wear wrist guards and kneepads. Not only were more males skating, with less protective gear, but table 2 also shows that males were nearly twice as likely as females to skate on streets $(13.3 \% v 7.6 \%)$.

Table 3 shows the percentage of skaters using the four types of protective equipment by skill level. Skaters in the beginner group were significantly more likely to wear all four types of gear. Use of helmets, elbow pads, and kneepads dropped for average skaters and then increased for advanced skaters. Use of wrist guards was highest among beginners, then declined for average skaters, and declined further for advanced skaters.
W, Suite 201, Washingto DC, 20005 USA (email: sosberg@prodigy.net) 
Table 1 Demographic and background information on in-line skaters $(n=2210)$

\begin{tabular}{ll}
\hline & No (\%) \\
\hline Gender & $1516(68.6)$ \\
Male & $694(31.4)$ \\
Female & \\
Age & $35(1.6)$ \\
$0-12$ & $106(4.8)$ \\
$13-17$ & $2038(92.2)$ \\
$18-50$ & $31(1.4)$ \\
$51+$ & $171(7.7)$ \\
Skill & $1860(84.2)$ \\
Beginner & $177(8.0)$ \\
Average & \\
Advanced & $892(40.4)$ \\
Weekday & $1318(59.6)$ \\
Yes & \\
No & $585(26.5)$ \\
Temperature $\left({ }^{\circ} \mathrm{F}\right)$ & $890(41.9)$ \\
$<70$ & $650(30.6)$ \\
$70-79$ & $255(11.5)$ \\
$80+$ & $337(15.2)$ \\
Location & $1618(73.2)$ \\
Street & \\
Sidewalk &
\end{tabular}

Table 2 Protective gear use and skating location by gender

\begin{tabular}{llll}
\hline & Male & Female & Total \\
\hline \% Using gear & & & \\
$\quad$ Helmet & 5.6 & 5.9 & 5.7 \\
Elbow pads & 9.3 & 11.4 & 10.0 \\
Knee pads & 20.1 & 28.6 & 22.8 \\
$\quad$ Wrist guards & 54.7 & 73.2 & 60.5 \\
Skating location (\%) & & & \\
$\quad$ Street & 13.3 & 7.6 & 11.5 \\
Sidewalk & 15.4 & 14.8 & 15.2 \\
Bike path & 71.2 & 77.5 & 73.2 \\
Total & 99.9 & 99.9 & 99.9 \\
\hline
\end{tabular}

$\star \star \star \mathrm{p}<0.001$

Table 3 Protective gear use by skill (\% using each type of gear)

\begin{tabular}{lllll}
\hline & $\begin{array}{l}\text { Beginner } \\
(n=171)\end{array}$ & $\begin{array}{l}\text { Average } \\
(n=1850)\end{array}$ & $\begin{array}{l}\text { Advanced } \\
(n=177)\end{array}$ & $p$ Value \\
\hline Helmet & 10.5 & 5.1 & 7.3 & 0.01 \\
Elbow pads & 22.2 & 8.3 & 15.8 & 0.001 \\
Knee pads & 39.2 & 21.1 & 24.9 & 0.001 \\
Wrist guards & 74.3 & 60.1 & 52.0 & 0.001
\end{tabular}

In table 4, the four types of protective gear are considered together. The two largest categories are comprised of skaters who wore no protective gear $(n=824)$ and those who wore only one type of gear $(n=839)$; 539 skaters wore two to four types of gear. Only independent variables that were significantly related to use of protective gear are depicted in the table. Females, skaters age $0-12$ and 50+, beginners, and skaters on bicycle paths wore the most protective gear.

Results not reported in tables show that among street skaters none were in the beginner category, compared with $9.2 \%$ beginners on sidewalks, and $8.7 \%$ on bicycle paths $(p<0.001)$. Use of protective gear was not significantly related to the weekday or weekend, number of passing skaters per hour, temperature, or month observed.

\section{Discussion}

Males are at higher risk for all types of injuries, ${ }^{10}$ including skating related injuries. ${ }^{45}$ Ellis reports that, "Approximately twice as many boys as girls were injured in sports-related activities as compared to a 4 to 1 ratio in in-line skating". ${ }^{5}$
Table 4 Significant predictors of use of skate protective gear

\begin{tabular}{lllll}
\hline & $\begin{array}{l}\text { Nogear } \\
(n=824)\end{array}$ & $\begin{array}{l}1 \text { piece } \\
(n=839)\end{array}$ & $\begin{array}{l}2-4 \\
(n=539)\end{array}$ & $p$ Value \\
\hline Gender & & & & \\
$\quad$ Female & 25.4 & 44.0 & 30.6 & 0.001 \\
$\quad$ Male & 43.1 & 35.3 & 21.6 & \\
$\quad$ Total & 37.5 & 38.0 & 24.4 & \\
Age & & & & \\
$\quad 0-12$ & 28.6 & 17.1 & 54.3 & 0.001 \\
13-17 & 63.2 & 20.8 & 16.0 & \\
18-50 & 36.5 & 39.5 & 24.0 & \\
50+ & 25.8 & 22.6 & 51.6 & \\
$\quad$ Total & 37.5 & 38.0 & 24.4 & \\
Skill & & & & \\
Beginner & 22.8 & 35.1 & 42.1 & 0.001 \\
Average & 38.1 & 39.2 & 22.7 & \\
Advanced & 45.2 & 28.8 & 26.0 & \\
$\quad$ Total & 37.4 & 38.1 & 24.5 & \\
Location & & & & \\
$\quad$ Street & 52.2 & 28.2 & 19.6 & 0.001 \\
$\quad$ Sidewalk & 40.9 & 34.4 & 24.6 & \\
$\quad$ Path & 34.5 & 40.4 & 25.2 & \\
$\quad$ Total & 37.5 & 38.0 & 24.4 & \\
\hline
\end{tabular}

Note: all cells have expected frequencies $>5$.

Schieber and Branche-Dorsey hypothesized this may be due to (1) more males skating than females; (2) lesser ability of males; or (3) more risky behavior among males (p429). ${ }^{4}$

Our data support two out of three of these explanations. ${ }^{4}$ In Boston, one would expect more male skaters to be injured because males comprise about $70 \%$ of skaters and they take greater risks. Not only do they wear less protective equipment, they are also more likely to skate on streets with traffic. Our data do not support the notion, however, that more males are injured because they are less skilled.

There is some evidence that beginners are at higher risk for sustaining skating related injuries. In their case series of 57 injured skaters in New York and Chicago, Callé and Eaton report that $60 \%$ were novice skaters and 30\% were intermediate. ${ }^{3}$ Similar findings have been reported for roller skaters. ${ }^{112}$ However, a recent study claims that advanced skaters are at higher risk of injury. ${ }^{13}$ More experienced skaters tend to skate at more dangerous locations such as on the street, perform tricks, and skate more hours, making them more prone to injury than novice skaters. The conventional wisdom that novice skaters are at higher risk of injury may be a dangerous myth encouraging skaters to stop wearing protective equipment when they become more proficient.

This study is based on observation of 2210 skaters in one section of Boston in 1996 and 1997. Percentages of skaters wearing various types of protective gear would likely differ in other cities, as would the percentage wearing gear in Boston over time. Generalizability is limited given the geographic and time bound nature of these data.

\section{Implications for prevention}

The low percentage of skaters observed wearing helmets $(5.7 \%)$ is appalling. Two papers by Schieber and colleagues focus on head injury. ${ }^{414}$ Although the incidence of head injury is much lower than other types of skating injuries, head injuries can result in serious long term disabilities. It is important to dispel popular myths that helmets are uncomfortable, 
unnecessary at certain times (for example, when skating on paths away from motorists), or unnecessary for certain individuals (for example, experienced skaters).

According to our data, young males are at highest risk of skating related injuries because they skate more, are more likely to skate in dangerous locations, and wear less protective gear than females. Given the higher risks for males, clinicians and public health experts need to target males for prevention efforts. Convincing males to follow the "rules of the road" and to wear protective gear would reduce the number and severity of injuries.

Along with males, moderately skilled and expert skaters should also be targeted for injury prevention efforts. These data show that moderately skilled skaters are less likely to wear protective gear than either beginning or advanced skaters. Motivating these average skaters to emulate more safety conscious advanced skaters would be a major public health accomplishment. Convincing average and expert skaters to always wear all the gear would prevent many head and extremity injuries.

An earlier version of this paper was presented at The 4 th World Conference on Injury Prevention and Control in Amsterdam the Netherlands, 18 May 1998.
1 Rollerblade Inc. Rollerblade HO: our story. Web site URL: http://www.rollerblade.com, 1996.

2 Callé SC. In-line skating injuries, 1987 through 1992. Am F Public Health 1994;84:675.

3 Callé SC, Eaton RG. Wheels-in-line roller skating injuries. 7 Trauma 1993;35:946-1.

4 Schieber RA, Branche-Dorsey CM. In-line skating injuries. Epidemiology and recommendations for prevention. Sports Med 1995;19:427-32.

5 Ellis JA, Kierulf JC, Klassen TP. Injuries associated with in-line skating from the Canadian hospitals injury reporting and prevention program database. Can $\mathcal{F}$ Public Health 1995;86:133-6.

6 Jacques LB, Grzesiak E. Personal protective equipment use by in-line roller skaters. F Fam Pract 1994;38:486-8.

7 Young CC, Mark DH. In-line skating. An observational study of protective equipment used by skaters. Arch Fam Med $1995 ; 4: 19-23$.

8 Warda L, Harlos S, Kassen TP, et al. An observational study of protective equipment use among in-line skaters. Inj Prev 1998;4:198-202.

9 Office of Research and Statistics. Neighborhood health status report: the health of Back Bay. Boston: Division of Public Health. Trustees of Health and Hospitals Inc, City of Boston, 1994.

10 Rice DP, MacKenzie EJ, and Associates. Cost of injury in the United States: a report to Congress. San Francisco, CA: Institute for Health and Aging, University of California and tute for Health and Aging, University of California and
Injury Prevention Center, Johns Hopkins University, 1989.

11 Ferkel RD, Mai LL, Ullis KC, et al. An analysis of roller skating injuries. Am $\mathcal{F}$ Sports Med 1981;10:24.

12 Kvidera DJ, Frankel VH. Trauma on eight wheels: a study of roller skating injuries in Seattle. Am $\mathcal{F}$ Sports Med 1983;11: 38.

13 Seldes RM, Grisso JA, Pavell JR, et al. Predictors for injury among adult recreational in-line skaters: a multicity study. among adult recreational in-line skaters:

14 Schieber RA, Branche-Dorsey CM. Ryan GW. Comparison of in-line skating injuries with rollerskating and skateboarding injuries. $\mathcal{F} A M A 1994 ; 271: 1856-8$.

\section{Italy's new helmet law}

Italy recently enacted a country wide motorcycle helmet law, having the distinction of being the last EC country to do so. Until now, helmets have been mandatory only for minors and motorbike drivers with engines of $125 \mathrm{cc}$ or more, with compliance of about one third of the relevant population. This time it looks like the Italians mean business; fines of $\$ 30$ for an unbuckled helmet, up to $\$ 70$ for no helmet, and $\$ 120$ for a minor without a helmet will be levied by the police force. In a country where one in five persons drives a motorcycle or motorbike, the new law could save many lives.

There was general compliance throughout Italy, at least initially; police were out in force on the first day, though many feel the level of enforcement will be difficult to maintain. Things did not get off to the best start for the Rome police, however; 70 motorini, which police use to scoot about Rome, were grounded because their supply of helmets did not arrive in time. Naples had more success; police ticketed 890 persons by mid-afternoon.

The fashion consequences of the new law are taken very seriously in Italy. In light of the aesthetic concerns, at least one designer has designed chic helmets to minimize the damage to driver esteem. Hairdressers even took to the airwaves and a local Roman newspaper to demonstrate how women could maintain the "locks blowing in the wind" effect and advised what curlers to use for hairstyle preservation while wearing a helmet.

Sadly, the safety message inherent in the new helmet law has been somewhat lost in all the fanfare. Every sixth traffic fatality in Europe occurs in Italy, and studies show that only 10\% of the populace actually uses their seat belt, despite a 1988 law making such use mandatory. Perhaps serious enforcement and continual efforts to educate the Italian public about road safety can convince them that flouting this particular law is not in their best interests. - Angela Seay 